\title{
Some Economics of Digital Content
}

\section{Wilfred Dolfsma}

\begin{tabular}{|l|l|}
\hline \multicolumn{2}{|l|}{ ERIM REPORT SERIES RESEARCH IN MANAGEMENT } \\
\hline ERIM Report Series reference number & ERS-2004-036-ORG \\
\hline Publication & May 2004 \\
\hline Number of pages & 20 \\
\hline Email address corresponding author & w.dolfsma@fbk.eur.nl \\
\hline Address & Erasmus Research Institute of Management (ERIM) \\
& Rotterdam School of Management / Rotterdam School of Economics \\
& Erasmus Universiteit Rotterdam \\
& P.O.Box 1738 \\
& 3000 DR Rotterdam, The Netherlands \\
& Phone: +31 10 408 1182 \\
& Fax: +31 10 408 9640 \\
& Email: info@erim.eur.nl \\
& Internet: www.erim.eur.nl \\
\hline
\end{tabular}

Bibliographic data and classifications of all the ERIM reports are also available on the ERIM website: www.erim.eur.nl 


\title{
ERASMUS RESEARCH INSTITUTE OF MANAGEMENT
}

\author{
REPORT SERIES \\ RESEARCH IN MANAGEMENT
}

\begin{tabular}{|c|c|c|}
\hline \multicolumn{3}{|c|}{ BIBLIOGRAPHIC DATA AND CLASSIFICATIONS } \\
\hline Abstract & \multicolumn{2}{|c|}{$\begin{array}{l}\text { The music industry is currently subject to changes influenced by ongoing digitalisation and } \\
\text { informatization that are unprecedented. Other sectors can expect to undergo in the near future } \\
\text { what the media industry is going through now - the movie industry being a prime suspect. Each } \\
\text { day, some } 600,000 \text { copies of movies are exchanged via the Internet, most of these in violation } \\
\text { of the copyright laws. The disruptive nature of technological development makes that the } \\
\text { market for entertainment products and other content undergoes fundamental changes. Where } \\
\text { 'content' used to be exchanged attached to a physical carrier, increasingly it has the features of } \\
\text { an information product. }\end{array}$} \\
\hline \multirow{3}{*}{$\begin{array}{l}\text { Library of Congress } \\
\text { Classification } \\
\text { (LCC) }\end{array}$} & $5001-6182$ & Business \\
\hline & $5546-5548.6$ & Office Organization and Management \\
\hline & HF 5469.7 & Markets \\
\hline \multirow{3}{*}{$\begin{array}{l}\text { Journal of Economic } \\
\text { Literature } \\
\text { (JEL) }\end{array}$} & $\mathrm{M}$ & Business Administration and Business Economics \\
\hline & $\begin{array}{l}\text { M } 10 \\
\text { L } 2\end{array}$ & $\begin{array}{l}\text { Business Administration: general } \\
\text { Firm Objectives, Organization and Behaviour }\end{array}$ \\
\hline & D 4 & Market Structure and Pricing \\
\hline \multirow{3}{*}{$\begin{array}{l}\text { European Business Schools } \\
\text { Library Group } \\
\text { (EBSLG) }\end{array}$} & $85 \mathrm{~A}$ & Business General \\
\hline & $\begin{array}{l}100 B \\
240 B\end{array}$ & $\begin{array}{l}\text { Organization Theory (general) } \\
\text { Information Systems Management }\end{array}$ \\
\hline & $290 \mathrm{~A}$ & New product development \\
\hline \multicolumn{3}{|c|}{ Gemeenschappelijke Onderwerpsontsluiting (GOO) } \\
\hline \multirow[t]{3}{*}{ Classification GOO } & 85.00 & Bedrijfskunde, Organisatiekunde: algemeen \\
\hline & $\begin{array}{l}85.05 \\
85.08\end{array}$ & $\begin{array}{l}\text { Management organisatie: algemeen } \\
\text { Organisatiesociologie, organisatiepsychologie }\end{array}$ \\
\hline & 85.40 & Marketing \\
\hline \multirow[t]{3}{*}{ Keywords GOO } & \multicolumn{2}{|c|}{ Bedrijfskunde / Bedrijfseconomie } \\
\hline & \multicolumn{2}{|c|}{ Organisatieleer, informatietechnologie, prestatiebeoordeling } \\
\hline & \multicolumn{2}{|c|}{ Internet, markt, digitalisering, productdifferentiatie, consumentengedrag } \\
\hline Free keywords & \multicolumn{2}{|c|}{$\begin{array}{l}\text { Internet market, digital content, product differentiation, price discrimination, consumer as } \\
\text { subcontractor, product development }\end{array}$} \\
\hline
\end{tabular}




\section{Some Economics of Digital Content}

Wilfred Dolfsma

Erasmus University Rotterdam \& Maastricht University

The music industry is currently subject to changes influenced by ongoing digitalisation and informatization that are unprecedented. Other sectors can expect to undergo in the near future what the media industry is going through now - the movie industry being a prime suspect. Each day, some 600,000 copies of movies are exchanged via the Internet, most of these in violation of the copyright laws. ${ }^{1}$ The disruptive nature of technological development makes that the market for entertainment products and other content undergoes fundamental changes. Where 'content' used to be exchanged attached to a physical carrier, increasingly it has the features of an information product.

This chapter will discuss only a few of the many changes that content industries undergo. These relate to the transition in the kind of product exchanged and the way in which it is exchanged. More specifically, I will discuss product differentiation and price discrimination as two important features of the relationship between retailer and consumer. Partly related to this is the industry dynamics one should expect, some of these are also discussed in this contribution. The market dynamics as well as the industry dynamics for information goods differs significantly from that of physical goods. Of course, the market for content will, certainly not in the foreseeable future, not be a perfect information market. Physical content products will continue to be sold. Still, the market for digital content will affects developments in the market for physical content. This will certainly be felt by firms in their ability to set prices, but may also be observed in the kind and number of newly released pieces of music. As such, the discussion here is relevant for content industries not affected by digitisation in the near future.

\footnotetext{
${ }^{1}$ The Economist (2002) “Movies and the Internet: Napster all over again?” 23 maart, p.63; Wired (1999) "It's Playback Time!: And MP3 is only the Beginning," 7(9), August, pp.122ff.
} 


\section{Content Industries}

Content may be defined, looking at the use of communication infrastructures such as Internet, as the information exchanged that is not necessary to maintain the infrastructure itself.

Content includes entertainment people seek, but includes personal exchange of emails as well. I will focus mostly on the information exchanged by people via the Internet that is unrelated to their professional activities. To give an indication of the extent to which the Internet is used for purposes other than 'functional' ones, observe Table 1 showing the most sought keywords.

Table 1: The Most Popular Search Words

\begin{tabular}{|l|}
\hline Gambling \\
\hline Sex \\
\hline Casino \\
\hline Porn \\
\hline Investing \\
\hline Hardcore \\
\hline Movie \\
\hline Nude \\
\hline xxx \\
\hline Game \\
\hline
\end{tabular}

Source: www.keywordcity.com (September25, 2003)

Content is in large part is the product of the deliberate efforts of individuals and organizations to be creative. Economists argue that the market offers insufficient benefits for individuals and organisations to be creative, giving rise to a need for Intellectual Property Rights such as copyrights (Landes \& Posner 1989). Unlike patents that protect the idea for a new good or production process, copyrights protect the specific way in which an idea is expressed; it protects 'original works of authorship'. Music, movies, books, computer code but also fragrances for perfume for instance may all be protected under copyright law. A 1998 OECD study discusses what it called 'copyright industries'. These are industries that produce goods the exploitation of which can be limited under copyright law. Copyright law is an intellectual property right such as patent law and trademark law. It restricts the commercial exploitation of a newly developed good to the person or organisation that has developed it. The holder of the copyrights may chose not to exercise his rights; rights may also be traded in the market or 
granted to a third party. There are some exceptions that limit the extent to which the holder of copyrights may exercise his rights. The work may be cited, and copies may be made by an individual for private, non-commercial purposes (referred to as 'fair use' or 'fair dealing'). Copyright laws differ across countries. An important difference is between the Anglo-Saxon system and the Continental European one. In the latter, a so-called moral right is given to the original author in addition to the commercial rights. A moral right is an inalienable right that prevents people that may have otherwise legally procured a good from altering it. Obviously, there is more content than produced by these copyrights industries. As copyrights do not need to registration, any 'original works of authorship' is protected, including personal messages. Many will not be aware that their email messages are protected by copyright too, but their commercial value is very likely to be nil. Content industries, media industries and copyrights industries may, thus, for the purpose of this chapter, be used as synonyms.

At present, one cannot understand the goings on in content industries without understanding the role copyrights play (Huygens et al. 2001; Klaes 1997). Firms producing and distributing works that are protected by copyrights typically rely on these rights; they allow them to weather downturns and they constitute de facto entry barriers. Examples of such 'original works of authorship', literary and artistic works in fixed form, include writings, music, drawings, dances, computer programs, and movies. In recent years databases have also come to be protected under copyright law (Mauer \& Hugenholz 2001). Ideas, concepts, principles, algorithms, and 'brute' facts are not included. The first time copyrights were formally enacted was in the English Statute of Anne (1709) in the UK, based on informal previous practice.

Copyright law protects the expression of an idea, rather than the idea itself; one merely has to able to prove anteriority. Copyrights can be considered to provide weaker protection than patents do as patents protect the idea whereas copyrights the particular expression of an idea. If the same idea is expressed in ways that are sufficiently different, both expressions will be protected from imitation without each infringing on the other. On the other hand, copyrights' duration is longer, generally lasting for the life of the author plus 70 years. There is an overall increase in the duration copyrights provide protection. The Statute of Anne provided protection for 14 years (once renewable). Since 1993 in Europe and 1998 in the USA the term mentioned above holds. One does not have to apply in order for one's creative work to be protected under copyright law, although having copyrighted work registered in some countries facilitates legal action against infringement. Copyrights actually refer to a 
number of different though related rights to such works. Copyrights are exclusive right to use or authorize others to use the work on agreed terms. It includes reproduction in various forms, recordings of it, its broadcasting, its translation into other languages, or -more controversially- its adaptation, such as a novel into a screenplay. So-called 'neighboring rights' have been added in recent years, preventing the public performance of a work without consent from and payment of royalty to the author. Some limitations to copyrights have been discussed briefly above.

\section{Media, Copyrights and Technology}

Within the discipline of economics, a separate field of economics of information has emerged (Ripley 2001), recently acknowledged when Akerlof, Spence and Stiglitz won the Nobel Prize in 2001. Information goods increasingly take on a central place in economic reality, whether it be pure information goods, or the information component of physical goods. A number of goods that previously were inseparable from a physical object, now become or can be

digitised. One may think of books, video material, or audio material. Certainly the emerging 'market' for digitised music has caught the attention over the past few years, shaking up as it did a sector in the economy that many people take a particular interest in, a sector that had also developed some degree of complacency. Internet and other technical means of communicating and exchanging information allow for an easier copying and distributing of information, in fact driving down marginal costs of such activities. This is in a way attractive for producers and distributors of information, but it also posses a threat. Others, particularly those who might otherwise have purchased the information, may now obtain the information from other sources, possibly at strongly reduced prices. This would in many cases be an infringement of the copyrights held in such works. Developments in technology have put pressure on the system of copyright law in previous decades as well by reducing the effort it takes to make copies (Burke 1996), but now the threat seems particularly acute (Schmidt et al. 2003). 
Table 2: A Glance at Content / Entertainment Markets

\begin{tabular}{|c|c|c|c|c|c|}
\hline & World & USA & Japan & $\overline{\mathrm{UK}}$ & $\begin{array}{l}\text { The } \\
\text { Netherlands }\end{array}$ \\
\hline $\begin{array}{l}\text { Revenues music recordables } \\
\text { (US\$, m, 2002) }\end{array}$ & $30,980.9$ & 12,609 & 5,001 & 2,936 & 397.6 \\
\hline $\begin{array}{l}\text { Music copyrights, gross } \\
\text { royalties (US\$, m, 2002) }\end{array}$ & $6,626.78$ & $1,940.42$ & 759.64 & 669.73 & 176.57 \\
\hline Production Long Films (\#) & & $420^{\mathrm{a}}$ & 238 & $78 t$ & $16^{\mathrm{a}}$ \\
\hline Cinema, attendance (m) & & $63 \ddagger$ & $123^{\mathrm{a}}$ & $114.6 \$$ & $16^{\mathrm{a}}$ \\
\hline Cinema, box office (US\$, m) & & $5,250 \ddagger$ & $153,580^{\mathrm{a}}$ & $384 \dagger$ & $188^{\mathrm{a}}$ \\
\hline $\begin{array}{l}\text { Daily Newspapers, } \\
\qquad(\# \text { titles, 1996) }\end{array}$ & & 1520 & 122 & 99 & 38 \\
\hline Books, \# titles & & (n.a.) & $3,401 \dagger$ & $2,853 \dagger$ & $11,002^{\circ}$ \\
\hline $\begin{array}{r}\text { Books, trade balance, } \\
\text { (\# copies, 1997) }\end{array}$ & & 689,001 & $-145,195$ & 855,714 & $-24,900$ \\
\hline $\begin{array}{l}\text { Radio receivers } \\
\qquad(/ 1000 \text { inhabitants, 1997) }\end{array}$ & & 2116 & 956 & 1443 & 980 \\
\hline $\begin{array}{l}\text { Television sets } \\
\qquad(/ 1000 \text { inhabitants, 1997) }\end{array}$ & & 806 & 686 & 521 & 519 \\
\hline $\begin{array}{l}\text { Leisure software (games, } \\
\text { US\$, m, 2000) }\end{array}$ & 21.61 & 7.48 & 3.99 & 1.55 & \\
\hline Internet domains & $31,987,198$ & & & & \\
\hline $\begin{array}{l}\text { Information on the Internet } \\
\text { (terabytes) }\end{array}$ & 532,897 & & & & \\
\hline
\end{tabular}

Sources: IFPI (2003), NMPA (2002), UNESCO (1999), Spectrum Strategy Consultants (2002); P. Lyman and H.R. Varian, "How Much Information", 2003. Retrieved from http://www.sims.berkeley.edu/how-much-info-2003 on [December 10, 2003]. Notes: ${ }^{\circ} 1993 ;{ }^{\text {a }}$ 1994; † 1996; +1995.

Information and communication technology (ICT) very rapidly and substantially changes our economy and society (Perez \& Soete 1988). In times of changing techno-economical paradigms, it is not easy to make predictions. However, some comments can be made on the developments media will face in the future. Information goods have properties that make 
them distinct from the goods exchanged on markets that generally figure in economic theories. Consumption by one person does not exclude in any way the consumption by others. In addition, and especially using ICTechnology, information goods may be consumed by several (many) individuals at the same time without either of them having an experience that is diminished in any way. Information goods are, thus, non-excludable and non-rivalrous. Information, therefore, is a (quasi-) public good.

Information products are not subject to damage through use or as a result of copying. A clandestine party, and even a customer, can benefit from the economic advantages of having manufactured such a product by unlawfully acquiring and marketing it. The options for unlawful uses are many; the result of such arbitrage is a decline of the product's price. In addition, copies cannot be distinguished from the originals. For this reason, the price of the used, second-hand product does not alert the customer of the quality of the original. Secondhand markets no longer give the quality-signals of the corresponding first hand products (cf. Akerlof 1970). A third feature of information products is that they can easily be modified. One could primarily think of modifications due to market developments or based on customer preference. Uncertainty for consumers increases, as the possibility to compare a product with others decreases. Providing demo versions does not completely solve this problem of information-asymmetry, inherent to information products, however. How should a customer judge the genuineness of the demo he or she is given if he is not able to determine how representative the demo is? Problems of information asymmetry are difficult to solve, unless by recourse to the reputation of the firm selling the product. Reputation is thus a valuable asset firms in markets for information goods. Reputation can be hard to attain (Kuran ) incumbent, well-endowed firms have an advantage in this regard. Attempts at manipulating intermediaries are tempting, and seem to be an inevitable part of the industry. For the music industry they are particularly well known and even studied by economist (Coase 1979).

For these reasons larger firms producing content have an advantage. Their advantage is also due to the strong network effects in market where information goods are exchanged (Shapiro \& Varian 1999). Consumption or use of information goods by some makes it more attractive for others to also start consuming the good. Each additional member of the group increases the value to the existing members of being a part of the group, for example by using the information good. The product itself can be configured such that network effects are made better use of, for instance by playing into the social elements of consuming content. ${ }^{2}$

\footnotetext{
${ }^{2}$ See Mitchell (1997), Frith (1996), Stahl (1997) and Dolfsma (2004b).
} 
Another option is to make the products technically or thematically compatible with complementary goods.

Discussed, or at least mentioned, much more extensively is another characteristic of information goods. Information goods tend to have a distinct cost structure: creating a first issue involves high investment costs that are to a large degree sunk cost. Such costs need to be invested, but, to the extent that they are sunk, cannot be recovered if the project fails. They are idiosyncratic to the product or project. Budgets for producing a movie, a computer game, or a piece of music have multiplied over the past years. Marketing budgets have increased even more, as the supply of content has grown and diversified; being noticed is more difficult. Costs already 'sunk' in the project, must not but often are considered in a decision about whether or not to continue. If, against the economic logic, a firm investing in the creation of an information good decides to continue anyway, it may come in a position, when the product can be brought to the market, where it decides to try to generate whatever cash flow it can to at least recover variable costs and some of the fixed costs. The firm will thus cut prices, forcing other players in the field to adjust prices as well.

High initial investment costs and low marginal or variable cost are an important consideration for firms in designing their strategy. A high investment, to be born before the product developed or produced can be marketed, implies that firms run a risk. If the product does not find a (sufficiently large) market, such costs will not be recovered. The sunk cost effect will be especially strong for markets where information products are exchanged. Alternatively, competitors can easily imitate an information product. Intellectual Property Rights (IPRs) of various kinds, which legally protect the products of the intellect from being commercially exploited by or in the name of parties other than the creator/author, are only a partial protection from such imitation.

Legal protection is, however, only one element of what might be called the 'appropriability regime' of a product, determining the extent to which the innovative firm can appropriate the profits, or benefits more generally, associated with the product (Teece 1986). Another is the 'nature of technology', conceived broadly (see, e.g., Dolfsma 2001). If, for instance, a (new) product must be produced using a new production process and is critically dependent on this process, the likelihood of imitation are diminished as process innovations need to be 'read' from a product. New content are forms of products innovations. ICTechnology effects the production and distribution of content; as such it facilitates process innovation. In addition, the production of new content depends on tacit knowledge of people 
involved, it is not so likely that the product can be imitated - one needs to be knowledgeable of previous content not only to be accepted by your peer producers of content, but also to be creative (Crane 1992, Shuker 1994). Links with other parties, such as in (r)etail, the media, or organisations in the business of life performances are important complementary assets (Vogel 1998), and often rely on personal contacts (Aksoy \& Robins 1992; DeFillippi \& Arthur 1998; Jones \& DeFillippi 1996; Eberts \& Norcliffe 1998). In the interactions between musicians and the staff responsible for production, tacit knowledge plays an important role as well (Gillet 1996).

While ICT would be facilitating some of the technical aspects of the work of producers, these are not the critical capabilities that they have. Critical is the way they relate to the musicians. ${ }^{3}$ Contrary to expectations (Malone et al. 1989), ICTechnology does not produce the perfect market from economists' textbooks (cf. Brynjolfsson \& Smith 2000; Graham 1998; Dolfsma 1998). The ease of making versions of an information product gives competitors the opportunity to imitate cheaply but also gives the initial creator the possibility of catering to the different audiences and thereby increasing the revenues from an innovation - I will elaborate on this now.

\section{Price discrimination and Product Differentiation}

It is only recently that the Internet began to have an impact on society, an influence going beyond the confines of the universities and research laboratories where it had been in use for several decades. Still, the theoretical discussion that has preceded this section, as well an understanding of the industry studied, does allow one to make some predictions.

As a number of observers have indicated (a.o., Varian 1996, Reinartz 2001) the Internet provides ample opportunity to collect information about consumers' preferences on the basis of which one might adjust the products one offers as a firm ('versioning'), but on the basis of which one might also charge different prices to consumers with differing willingness to pay. Such price discrimination has different forms:

- First-degree price discrimination means that the producer sells different units of output for different prices and these prices may differ from person to person. This is known as perfect price discrimination.

- Second-degree price discrimination means that the producer sells different units of output for different prices, but every individual who buys the same amount of the good pays the

\footnotetext{
${ }^{3}$ On the relation between innovation and trust or 'culture' more generally, see e.g. O’Reilly \& Tushman (1997).
} 
same price. Thus prices depend on the amount of the good purchased, but not on who does the purchasing. A common example of this sort of pricing is volume discounts.

- Third-degree price discrimination occurs when the producer sells output to different people for different prices, but every unit of output sold to a given person sells for the same price. This is the most common form of price discrimination, and examples include senior citizens' discounts, student discounts, and so on.

Conditions for price discrimination to hold include the availability of information to discriminate between (groups of) consumers, and the absence of arbitrage between the groups or individuals addressed. The Internet would now seem to offer the possibility of first-degree price discrimination. People's willingness to pay is easy to determine, while the (menu) costs for re-pricing goods on the Internet decrease. There is, of course, the possibility that people will be upset when they learn that identical products are sold on different terms. As consumers become more sophisticated about buying on-line, this objection might disappear (Reinartz 2001).

Important in evaluating price discrimination in welfare economic terms is Figure 6. The total area below the demand curve signifies the utility to society when such a product would be available free of charge. Assume a given price $\left(\mathrm{P}_{0}\right)$. Area $\mathrm{R}$ is the revenue accruing to the firms in this market. Areas A and B are, however, of greatest import in a welfare analysis. A is the so-called consumers' surplus; it is the price which some consumers would have been willing to pay for a product, but, given the price prevailing in the market, did not have to pay. They can now spend it on something else. Area B is a dead-weight welfare (efficiency) loss, since the consumers here would like to have consumed the good, but the good is not offered at the price they are able or willing to pay.

Figure 1: Price discrimination

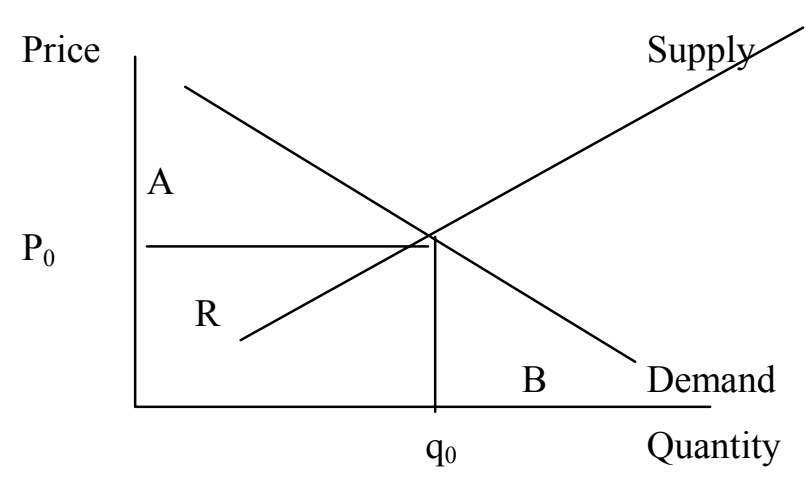


Price discrimination means that some consumers pay a higher price, but not all. More consumers may be able to consume the good. Price discrimination will most likely on the Internet be combined with product differentiation, making it hard to asses the consequences; consumers may have to be paying a higher price, but will also obtain a product that more closely meets their preferences. It is likely that the first effect will be stronger than the latter. Since they need to make idiosyncratic investments, they are more dependent on this relationship than the firms are (cf. Williamson 1985). It is only after an initial period where consumers invest in a relationship by filling in questionnaires, surfing on a site, and answering questions that they may expect the benefits of tailored products. As such, they may become the victims of opportunistic behaviour from the part of the firm; they are locked-in to a relation.

For pure information goods, marginal costs for producing an additional copy are or approach zero. Economic analysis would suggest that people should be able to obtain such a good at a price that equals marginal costs, a situation where public welfare would be greatest. The dead-weight loss of triangle B would not occur. At the same time, however, there would be no material incentive for people to create new information goods. IPR are an important element in such an incentive system. It involves introducing a measure of excludability where nothing like that exists naturally. A static consequence would be that the quantity of goods brought to the market will be more limited - a disadvantage. Dynamic consequences due to the incentive provided for creativity might, however, outweigh this. Do copyrights contribute to an incentive system that makes creative individuals produce more new ideas and products? The picture is unclear. Most of the benefits due to the existence of copyrights, at least for the music industry, accrue to intermediaries such as music publishers and record companies (Towse 1999; Dolfsma 2000). Particularly younger creative individuals are paid little, although they are most creative. ${ }^{4}$ Whether this points to an inherent need to be creative and express oneself, or on an (irrational) expectation that one will become one of the few stars in the system cannot be determined more conclusively (Abbing 2002).

On electronic markets consumers continuously provide information about their preferences and their willingness-to-pay. Firms can and do make use of that information directly in altering the (bundle of) product(s) they offer, and the price they offer it for. Rather

\footnotetext{
${ }^{4}$ On this particular point, as well as on the issue of motivation of individuals and the role of material incentives generally, see Frey (1997).
} 
than the trial-and-error process of taking a new product to the market and waiting to see if there will be demand for it, firms now know (much) more about their customers who in fact become subcontractors, becoming relatively more dependent on suppliers of digital content than the other way around, even thought the volatility of markets for content does limit the influence of providers.

\section{Content that binds}

In emerging electronic markets consumers are flooded with information that they need to filter and qualify. Intermediaries are in a much better position to perform these tasks than consumers themselves. Not only will they be able to exploit economies of scale and scope in gathering and interpreting information about products available on the Internet, but they will be able to strike deals with upstream suppliers to consider their products and bring them to the attention of consumers. Intermediaries' position will depend on their reputation in both the market where they buy products (information, usually) from suppliers, and where they sell to final consumers. Consumers in their turn, will appreciate the selection of information done for them by these intermediaries and will be willing to pay for these services.

With the use of the preferences that consumers reveal by their implicitly or explicitly stated choices, the intermediaries that form the last chain before the consumers are able to construct detailed consumer profiles. Answers to questions, information about previous purchases, as well as clicking behaviour, constitutes valuable information that intermediaries use to customize their products as well as their sales efforts. Since contemporary hardware and software become increasingly sophisticated, information gathering and subsequent profiling on the basis of that can be automated to a significant degree. Consumer profiles that intermediaries are able to construct become increasingly focused on single individuals. Indeed, firms' overall strategies are increasingly informed by such considerations. ${ }^{5}$ As consumers are, as such, increasingly involved in the production process itself - especially in the design and marketing aspects of it (if one can still legitimately distinguish between these aspects in cases such as these) - one may for that reason perceive of them as subcontractors to the intermediaries or suppliers (Dolfsma 2004).

Consumers and intermediaries may both benefit from these developments in electronic markets. Consumers benefit because they can save time searching for the products they want

\footnotetext{
5 A good, and some would say notorious, example is Microsoft (see Financial Times, December 31, 2001 "Microsoft's direct connection to the customer").
} 
and will even be offered items they might like but had not considered or known about until then, of a kind and quality that meets their preferences to higher degrees. Intermediaries will particularly benefit, however (Dolfsma, 1998). They are crucial gatekeepers as they control an important funnel of attention that consumers rely on to determine the quality and value of information goods (cf. Crane, 1992). It will be difficult for upstream suppliers to go around this bottleneck and reach consumers directly or establish their own intermediary. Intermediaries that have established a reputation have an advantage over new entrants in that they have already established links with (potential) consumers.

Given that digital products can easily be reproduced and versioned, and do not deteriorate if used or copied (Whinston et al., 1997), customisation of them is progressing and will continue to do so in the future. Consumers, however, need to convey information about themselves in order to secure these benefits of customisation. However this information is conveyed, it means much more investment in terms of time and money on the part of consumers than on the part of intermediaries. Intermediaries will do much of the information gathering and classifying by the use of special software. The extensive databases that are thus built can subsequently be used to fine-tune marketing efforts and offer customers products that will meet their preferences in better ways. Related products in which some interest may have been expressed can also be presented. Firms such as Amazon generate additional revenues efficiently and add to the profiles that they already have of other, similar people.

Since the cost of investing in a market relation between intermediary and consumer is much higher for the latter than for the former, and switching costs for a consumer are high, the investments of consumers can be considered as idiosyncratic investments in terms of transaction costs economics (Williamson 1975). These investments are idiosyncratic, because discontinuing the business relation in which investments were made and starting one with another intermediary means that the consumer has to enter into a process of providing implicit or explicit information about his preferences to this new partner afresh. Such investments make the party undertaking them dependent on the other party in the relation; he is locked into a relation. This second party may then use the leverage to extract higher rents from the relation.

Before making the investment, consumers may therefore need to be persuaded of the benefits they will reap from entering into such a relationship with an intermediary. Once this relationship has started, the investment involved in the investments made will prevent either party to abandon it. If one party has invested idiosyncratically, this party will be in an 
unfavourable position. Rational consumers may be aware of this and decline to enter into such a relation. If no alternative firms are available that will not build and use profiles to their own advantage, even rational and knowledgeable customers may have to enter into such a relation. What is more, statements of firms on electronic markets to the effect that they will not use people's information have been violated before. ${ }^{6}$ Olson's (1965) logic of collective action indicates that organizing many consumers to prevent firms from adopting the kind of policy discussed above will be insurmountably difficult. Customers are likely, in addition, to have to do without the benefits associated with such practices as well, however. When consumers are not rational and perfectly informed homo economici, but rather creatures of habit (e.g. Dolfsma 2002, 2004b), there is an additional reason why they will simply enter into a relation with an established, reputed firm and later find themselves in a subcontracting relation.

Consumers generally are aware of their investment, and if they are not yet aware they will rapidly become aware of it; their knowledge does not stop them, however, from participating in such a relationship. The potential benefits of decreased search costs and increased fulfilment of their needs may convince them that it is beneficial to initiate a relationship with a particular intermediary. Consumers may also appreciate it when they are pointed to different but related products. In addition, intermediaries in this early and immature state of many electronic markets have started to compensate (potential) customers for the personal and unique information they provide by answering questionnaires. This compensation takes the form of rebates or samples.

The balance of advantages and disadvantages for consumers and firms might be different for electronic markets. Why would intermediary firms necessarily be the parties that are likely to gain most? Even if they are to gain more than consumers, however, that gain may not be at the expense of Internet consumers. Total economic activity may expand due to developments in Internet markets. The additional consumer surplus may outweigh the deadweight loss that consumers suffer; in all the process may end up in a situation that is a Pareto improvement even when further welfare improvements would be possible. If it is, and if intermediaries take the bigger share of that market, the economic position of consumers need not deteriorate in absolute terms. Developments in electronic markets can increase the economic pie, even when they can change the distribution of the pie itself.

\footnotetext{
${ }^{6}$ Despite the public outcry that this has sometimes evoked, such action may not be illegal. Firms on electronic markets can have their customers sign 'click-wrap' contracts that many never read that contain clauses that allow them to alter their policy in relation to privacy without consent of their extant customers.
} 
Furthermore, two countervailing forces are at play in electronic Internet markets that set limits to the degree to which intermediaries can wield their market power. One is the fact that communities that form in the virtual world - for instance, in discussion groups - may find it more easy to organize themselves as they are not bound by geography and can more easily reach a critical mass. The likelihood that information about alternative intermediaries to turn to or about (alleged) abuses by the intermediary with whom community members now deal will disperse in the network or community is substantial. The background and sources of information at the disposal of each member of the community when he will likely differ significantly more than in traditional, physical markets. In network theory, this is known as the 'weak ties' argument, and for many different situations it has positive effects (see, e.g., Granovetter 1995). Especially Rheingold (1994) believes that Internet communities will be an important countervailing power in the social and the economic realm. Jones $(1995,1998)$ provides empirical studies of Internet communities that present a more mixed perspective. Extant relations tend to persist, or tend to be reflected in relations on the Internet; power is not absent from the Internet, contrary to what many had expected. Whatever effect Internet communities have on the behaviour of firms depends on firms wanting to preserve their reputation.

A second tendency that will be observed as electronic markets develop and mature is an increased volatility in demand on these markets. New products altogether, or new variants of an existing products are likely to find their way to the market. These will partly be delivered by entrants on electronic markets in an attempt to establish a foothold in a particular market, but may also be launched by incumbents as a means of constructing barriers to entry and defend their own position on a market. Such practices by incumbents are already known for certain physical markets such as cereals, soaps, washing powders, and detergents (cf. Scherer and Ross, 1990) and will be copied and perfected on Internet markets.

Whether or not incumbents will succeed in maintaining their possibly dominant positions in electronic markets depends on how responses to their behaviour is perceived and acted upon in the different Internet communities that are relevant to these firms. Internet communities have extended possibilities to express, in terms described by Hirschmann (1970), their voice, while their members may not always be able to exercise the exit option because they are locked into a relation with an intermediary that they themselves have invested in heavily. How this works out in terms of the absolute and relative numbers of customers who remain loyal to an intermediary firm and the products it brings to a market is 
not clear. The effect may be that the position of a firm will become less secure than it is in physical markets, but that need not necessarily result in its position inevitably deteriorating. Entertainment industries provide examples of industries where a fundamental feature of business is an equivalently high degree of demand volatility. Still these industries tend to be dominated by a few large companies (see Vogel, 1998), because large, diversified firms can take advantage of such circumstances while small, single-product firms are very vulnerable. Relevant Internet communities consist of large numbers of consumers with diverse interests. As Olson has argued persuasively already in 1965, a small group of parties that has a welldefined interest often finds it easy to mobilize against such a large(r) group. In addition, as Internet communities allow for people to communicate anonymously, parties (firms) that have a specific interest may be able to introduce information in the community through individuals that pose themselves as independent. Sony Music has notoriously done so by persuading a reviewer of newly released music to write favourably on its music. Future developments will thus, of course, have to decide which of these tendencies will be stronger.

\section{Organizing Product Innovations}

The ongoing existence of companies in the media industry is closely related to their capability not only of constantly developing new products, but also of targeting a large enough market with these products. The rate of success of new products in the media industry already used to be at a relatively low level of $10 \%$ in the 1960 s and 1970s (Peterson \& Berger 1975), but it has even declined in the years thereafter. $95 \%$ of music released nowadays does not even reach its break-even point. While, of course, the thorough selection before actual release of songs involves substantial costs as well. However, the few media products that actually are profitable handsomely compensate for the non-profitable others. The success of product innovations thus challenges the organisation of media companies. Scale is important to survive failures, but a certain feeling of the market is equally important. The latter is notoriously difficult for large corporations.

Given the pressure of illegal use on information product markets, producers are driven to constantly launch new products. It is a certain way to stay ahead of - unlawful competition. In addition, adapting products to every taste is a well-known strategy that has been initially analysed by the economist Hotelling (1929) in the case of ice cream parlours alongside beaches. Possibilities to influence success of a certain song through effective marketing are there, but of limited use as consumers are not perfectly malleable nitwits. 
The large incumbent players in the music industry - the "majors" - control the most important complementary assets that allow them to maintain and even improve their position over long periods of time despite the uncertainty in the market. For decades the 5 majors have a combined market share of $80 \%$ (Table 3 ) - the music industry is no exception among the entertainment industries. Deep (financial) pockets, distribution capabilities and marketing expertise are what large, existing corporations focus on - based on these capabilities, they are in the more advantageous position.

Table 3: The Five Major Record Companies (\% of sales, 2000),

\begin{tabular}{l|l}
\hline \hline & Global \\
\hline Universal & 21.1 \\
Sony & 17.4 \\
EMI & 14.1 \\
Warner - Time Warner & 13.4 \\
BMG - Bertelsmann & 11.4 \\
Independents & 22.6 \\
\hline Sources: Music Business Internat (MBI, 2000).
\end{tabular}

Sources: Music Business International (MBI, 2000).

Next to this negative reason to increase the pace of product innovation, there are several positive reasons. It is important for businesses in the media industry to launch new products in order to be ahead of competition and to make the most out of a certain market. Product life cycles have shortened, the fashion extent of the economy increases. Producing upgrades or versions of existing goods limits the costs of product innovation. Initial costs have already been made.

If businesses learn that a smaller percentage of new products prove successful, they must be able to survive unsuccessful releases. The period for raising profits from the market will shorten. Success has to be generated through short, highly agile, intensive and sophisticated advertisement, but there are additional means to use. A proven strategy is that of building on previous success by creating "platforms". Platforms can remain internal to the genre. The star system in the music industry is an example of such a platform strategy. Star musicians releasing a new album have less chance on the new production becoming a flop. Platforms can also transcend genres: Britney Spears who "writes" a book, or the Spice Girls who shoote a film are examples. Music proves to be a media product that can serve as 
platform itself, but it can rely on other platforms as well. Stars featuring in a film increase the chance for success of that production. The soundtrack of a Disney film, made by Elton John, is an example of this. One should not be surprised that the influence of companies in the media industry is widespread. The result is that for entertainment industries economies of scope are important. Being present in related fields allows you to leverage a successful product in related fields or genres as Table indicates.

Table 4: Economies of Scope in Entertainment Industries

\begin{tabular}{|c|c|c|c|c|c|c|c|}
\hline & Time Warner & Disney & Sony & Seagram & $\begin{array}{l}\text { Bertels } \\
\text {-mann }\end{array}$ & Viacom & Newscorp \\
\hline $\begin{array}{l}\text { Television, } \\
\text { production }\end{array}$ & $\sqrt{ }$ & $\sqrt{ }$ & $\sqrt{ }$ & $\sqrt{ }$ & $\sqrt{ }$ & $\sqrt{ }$ & $\sqrt{ }$ \\
\hline Film & $\sqrt{ }$ & $\sqrt{ }$ & $\sqrt{ }$ & $\sqrt{ }$ & $\sqrt{ }$ & $\sqrt{ }$ & $\sqrt{ }$ \\
\hline Music & $\sqrt{ }$ & $\sqrt{ }$ & $\sqrt{ }$ & $\sqrt{ }$ & $\sqrt{ }$ & & $\sqrt{ }$ \\
\hline Publishing & $\sqrt{ }$ & $\sqrt{ }$ & & & $\sqrt{ }$ & $\sqrt{ }$ & $\sqrt{ }$ \\
\hline $\begin{array}{l}\text { Television, } \\
\text { Broadcasting }\end{array}$ & $\sqrt{ }$ & $\sqrt{ }$ & & & $\sqrt{ }$ & $\sqrt{ }$ & $\sqrt{ }$ \\
\hline Cable television & $\sqrt{ }$ & $\sqrt{ }$ & $\sqrt{ }$ & $\sqrt{ }$ & & $\sqrt{ }$ & $\sqrt{ }$ \\
\hline Satellite television & $\sqrt{ }$ & & $\sqrt{ }$ & $\sqrt{ }$ & $\sqrt{ }$ & & $\sqrt{ }$ \\
\hline Internet & $\sqrt{ }$ & $\sqrt{ }$ & $\sqrt{ }$ & $\sqrt{ }$ & $\sqrt{ }$ & $\sqrt{ }$ & $\sqrt{ }$ \\
\hline Theme parks & $\sqrt{ }$ & $\sqrt{ }$ & & & & $\sqrt{ }$ & \\
\hline Retail & $\sqrt{ }$ & $\sqrt{ }$ & & & $\sqrt{ }$ & $\sqrt{ }$ & \\
\hline
\end{tabular}

Source: The Economist (1998) "Wheel of Fortune - A survey of technology and

Entertainment". 21 November.

The importance of a thorough feeling for the market will increase, implying the need for a very flexible way of organizing a big firm (Storper 1989; Hakfoort \& Weigand 2000). Major players in the entertainment industries thus seek agreements with smaller ones in order to take over talent that proved successful in local markets. Both players benefit from such an arrangement (Hesmondhalgh 1998). The kind of agreements that result are complex, offering a range of incentives to the players involved (Caves 2000).

\section{Some Conclusions}


Content industries are in a genuine maelstrom at the moment. Many developments affect them, many of those related to what might be called infomatization. Content increasingly is digital. Some developments stand out, however, and these offer opportunities to content producing firms and not just threats, but affect consumers too. Compiling extensive consumer profiles offers the possibility for unforeseen product differentiation and price discrimination. These derive from the fundamentally different characteristics of digital content (information) as compared to physical products. Consumers may even be perceived as becoming subcontractors to firms producing content. Still, past underpinnings of content industries (most notably copyrights) are potentially altered substantially, and so may affect the dynamics in the markets and industry structures.

\section{References}

Abbing, H. (2002) Why are artists poor? - The Exceptional Economy of the Arts. Amsterdam: Amsterdam UP. G.A. Akerlof, (1970) “'The Market for "Lemons': Quality uncertainty and the market mechanism," Quarterly Journal of Economics 84(3): 488-500.

Aksoy, A. en Robins, K. (1992) "Hollywood for the $21^{\text {st }}$ century" Cambridge Journal of Economics, 16(1): 1-22. Burke, A.E. (1996) "How Effective Are International Copyright Conventions in the Music Industry? Journal of Cultural Economics, 20(1): 51-66.

Brynjolfsson, E. \& Smith, M.D. (2000) "Frictionless Commerce? A Comparison of Internet and Conventional Retailers"Management Science 46(4): 563-585.

R.E. Caves (2000) Creative Industries - Contracts between Art and Commerce. Cambridge, MA, Harvard UP.

Coase, R.H. (1979) "Payola in Radio and Television Broadcasting" Journal of Law and Economics, 22(2): 269328

Crane, D. (1992) The Production of Culture - Media and the Urban Arts. Newbury Park, Ca.: Sage.

DeFillippi, R.J. \& Arthur, M.B. (1998) "Paradox of project-based enterprise: the case of film making, California Management Review, 40(2): 125-139.

W. Dolfsma (2004) "The Logic of Collective Consuming: Consumers as Subcontractors on Electronic Markets" International Journal of Social Economics, in print.

----, (2004b) Institutional Economics and the Formation of Preferences: The Advent of Pop Music. Cheltenham: Edward Elgar.

Dolfsma, W. (2002) "The mountain of experience: how people learn in a complex, evolving environment" International Journal of Social Economics, 29(8): 675-684

Dolfsma, W. (1998) “Internet: An Economist's Utopia?” Review of International Political Economy 5(4).

Dolfsma, W., (2000) "How will the music industry weather the globalisation storm?" First Monday - Peer reviewed journal on the Internet (www.firstmonday.org), 5(5).

Eberts, D. \& Norcliffe, G., New Forms of Artisinal Productions in Toronto's Computer Animation Industry, Geographische Zeitschrift, 86(2), 1998, 120-133.

C. Freeman \& C. Perez (1988) Structural Crises of Adjustment, Business Cycles and Investment Behaviour. in: 
G.Dosi, C. Freeman, R. Nelson, G. Silverberg \& L. Soete (1988) Technical Change and Economic Theory. London, Pinter.

Frey, B. (1997) Not Just for the Money. Cheltenham: Edward Elgar.

Frith, S. (1996) Performing Rites: On the Value of Popular Music. New York: Oxford UP.

Gillet, C. (1996 [1970]) The Sound of the City. (New York), 2nd edition.

Graham, S. (1998) "The end of geography or the explosion of place? Conceptualizing space, place and information technology" Progress in Human Geography 22(2): 165-185.

M. Granovetter (1995) Getting a Job. Chicago: The University of Chicago Press, $2^{\text {nd }}$ ed.

J. Hakfoort \& J. Weigand (2000) Magazine Publishing - A Quiet Life? The Dutch Market for Consumer Magazines. Den Haag, Centraal Planbureau http://www.cpb.nl/nl/pub/werkdoc/120/cm/

D. Hesmondhalgh (1998) The British Dance Music Industry. British Journal of Sociology 49(2): $234-251$.

A.O. Hirschman (1970) Exit, Voice and Loyalty. Cambridge, Mass.: Harvard UP.

Hotelling, H. (1929) "Stability in Competition.” Economic Journal 39: 41-57.

Huygens, M., C. Baden-Fuller, F.A.J. Van Den Bosch and H.W. Volberda (2001) "Co-evolution of Firm Capabilities and Industry Competition: Investigating the Music Industry, 1877-1997’ Organisation Studies 22(6): 971-1011.

Jones, C.\& DeFillippi, R.J. (1996) "Back to the future in film: combining industry and self-knowledge to meet the career challenges of the $21^{\text {st }}$ century" Academy of Management Executive 10(4): 89-103.

S.G.Jones (ed., 1995) Cybersociety. Thousand Oaks, CA.: Sage.

----, (ed., 1998) Cybersociety 2.0. Thousand Oaks, CA.: Sage.

Landes, W.M. \& Posner, R.A. (1989) “An Economic Analysis of Copyright Law” Journal of Legal Studies 18(juni): 325-363.

Klaes, M. (1997) “Sociotechnical Constituencies, Game Theory, and the Diffusion of Compact Discs” $\underline{\text { Research }}$ Policy, 25(8): 1221-1234.

Malone, T., J.Yates en R. Benjamin (1989) “The Logic of Electronic Markets” Harvard Business Review (mei/juni): 166-170.

S.M. Maurer, B. Hugenholz, en H.J. Onsrud (2001) “Europe’s Database Experiment” Science 294 (26 October), p. 789-790.

Mitchell, T. (1997) “New Zealand Music on The Internet: A Study of the NZPOP Mailing List” Perfect Beat, 3(2): 77-95.

Olson, M. (1965) The Logic of Collective Action. Cambridge, Mass.: Harvard UP.

Organisation for Economic Cooperation and Development (1998) Content as a New Growth Industry. Paris: OECD.

R.A. Peterson \& D.G. Berger (1975) Cycles of Symbol Production: the case of popular Music. American Sociological Review 40, p.158-173.

C.A. O’Reilly \& M.L. Tushman (1997) “Using Culture for Strategic Advantage: Promoting innovation through social control" in: M.L. Tushman \& P. Anderson (eds.) Managing Strategic Innovation and Change. New York: Oxford UP.

Reinartz, W.J. (2001) “Customising Prices in Online Markets” European Business Forum 6: 35-41.

H. Rheingold (1994) The virtual community. London: Stecker\&Warburg

C. Shapiro \& H.R. Varian (1999) Information Rules - A strategic guide to the network economy. Harvard 
Business School Press.

F.M. Scherer \& D. Ross (1990) Industrial Market Structure and Economic Performance. Boston: Houghton Mifflin, 3e ed.

Shuker, R. (1994) Understanding Popular Music. London: Routledge.

Spectrum Strategy Consultants (2002) From exuberant youth to sustainable maturity - Competitiveness analysis of the UK games software industry. Department of Trade \& Industry.

Stahl, G. (1997) “Citing the Sound: New Zealand Indie Rock in North America” Perfect Beat 3(2): 60-76.

Storper, M. (1989) “The transition to flexible specialisation in the US film industry" Cambridge Journal of Economics 13(2).

Teece, D.J. (1986) "Profiting from Technological Innovation: Implications for Integration, Collaboration, Licensing and Public Policy" Research Policy, 15.

Towse, R. (1999) "Copyright and Economic Incentives: An Application to Performers' Rights in the Music Industry," Kyklos 52(3): 369-390.

UNESCO (1999) Statistical Yearbook. Paris: UNESCO.

H.R. Varian (1996) "Differential Pricing and Efficiency” FirstMonday - Peer reviewed journal on the Internet 1(2) August (www.firstmonday.org).

Vogel, H.L. (1998) Entertainment Industry Economics. Cambridge: Cambrigde U.P.

A.B. Whinston, D.O. Stahl, and S.-Y. Choi (1997) The Economics of Electronic Commerce. Indianapolis, Ind.: Macmillan.

Williamson, O.E. (1975) Markets and Hierarchies: Analysis and Antitrust Implications. New York: Free Press. 


\section{Publications in the ERIM Report Series Research* in Management}

\section{ERIM Research Program: "Organizing for Performance"}

\section{4}

Learning And Governance In Inter-Firm Relations

Bart Nooteboom

ERS-2004-003-ORG

http://hdl.handle.net/1765/1122

Organisational Learning And Multinational Strategy

Bart Nooteboom

ERS-2004-004-ORG

http://hdl.handle.net/1765/1123

Density And Strength Of Ties In Innovation Networks: A Competence And Governance View

Bart Nooteboom and Victor A. Gilsing

ERS-2004-005-ORG

http://hdl.handle.net/1765/1124

Innovation, learning and cluster dynamics

Bart Nooteboom

ERS-2004-006-ORG

http://hdl.handle.net/1765/1125

Empirical Tests Of Optimal Cognitive Distance

Stefan Wuyts, Massimo G. Colombo, Shantanu Dutta, and Bart Nooteboom

ERS-2004-007-ORG

http://hdl.handle.net/1765/1126

Entrepreneurship in Transition: Searching for governance in China's new private sector

Barbara Krug and Hans Hendrischke

ERS-2004-008-ORG

http://hdl.handle.net/1765/1128

Exploring Emotional Competence: Its effects on coping, social capital, and performance of salespeople Willem Verbeke, Frank Belschak and Richard P. Bagozzi

ERS-2004-014-ORG

http://hdl.handle.net/1765/1174

The Impact of Business Ownership Change on Employee Relations: Buy-outs in the UK and the Netherlands Hans Bruining, Paul Boselie, Mike Wright and Nicolas Bacon ERS-2004-021-ORG

http://hdl.handle.net/1765/1263

* A complete overview of the ERIM Report Series Research in Management: https://ep.eur.nl/handle/1765/1

ERIM Research Programs:

LIS Business Processes, Logistics and Information Systems

ORG Organizing for Performance

MKT Marketing

F\&A Finance and Accounting

STR Strategy and Entrepreneurship 
Towards a Dynamic (Schumpeterian) Welfare Economics

Wilfred Dolfsma

ERS-2004-026-ORG

http://hdl.handle.net/1765/1264

The Three-Step Test-Interview (TSTI): An observational instrument for pretesting self-completion questionnaires

Tony Hak, Kees van der Veer and Harrie Jansen

ERS-2004-029-ORG

http://hdl.handle.net/1765/1265

Measuring the Knowledge Base of an Economy in terms of Triple-Helix Relations among 'Technology, Organization, and Territory'

Loet Leydesdorff, Wilfred Dolfsma \& Gerben van der Panne

ERS-2004-034-ORG

http://hdl.handle.net/1765/1300

Paradoxes of Modernist Consumption - Reading Fashions

Wilfred Dolfsma

ERS-2004-035-ORG

http://hdl.handle.net/1765/1330 